\title{
Pemanfaatan Tandan Kosong Kelapa Sawit untuk Produksi Jamur Tiram (Pleurotus sp.) dan Enzim Ligninase
}

\section{Utilization of Oil Palm Empty Fruit Bunches for Oyster Mushroom Growth (Pleurotus sp.) and Ligninolytic Enzyme Activity}

\author{
Dimawarnita $\mathbf{F}^{1}$, Perwitasari $\mathbf{U}^{2}$ \\ ${ }^{1}$ Pusat Penelitian Bioteknologi dan Bioindustri Indonesia, Jl. Taman Kencana No.1, Bogor 16151 \\ ${ }^{2}$ Pusat Penelitian Bioteknologi, Lembaga Ilmu Pengetahuan Indonesia, Jl. Raya Bogor km.46,Cibinong 16912
}

Dimawarnita F, Perwitasari U. 2017. Pemanfaatan Tandan Kosong Kelapa Sawit untuk Produksi Jamur Tiram (Pleurotus sp.) dan Enzim Ligninase. Jurnal Mikologi Indonesia 1 (2), $100-108$

\begin{abstract}
Abstrak
Tandan kosong kelapa sawit (TKKS) berpotensi dimanfaatkan secara integratif dan simultan untuk menghasilkan produk bernilai ekonomis tinggi, antara lain jamur tiram (Pleurotus sp.) dan enzim ligninase (Li-P, Mn-P dan lakase). Sistem teknologi secara simultan menghasilkan jamur konsumsi dan enzim ligninolitik (enzim oksidatif) yang dapat dilakukan dengan sistem fermentasi substrat padat TKKS dengan jamur tiram yang merupakan kelompok jamur pelapuk putih/JPP. Tujuan penelitian ini untuk mengembangkan teknologi integratif pengolahan biomassa pertanian (TKKS) dari perkebunan kelapa sawit secara simultan, mengubah TKKS menjadi barang bernilai jual tinggi melalui produksi jamur tiram dan enzim ligninase. Tahap pertama dilakukan pertumbuhan jamur tiram (putih, kuning, dan pink) pada media TKKS. Pertumbuhan jamur konsumsi dilaksanakan di tempat budidaya jamur tiram milik petani di Cianjur. Kemudian setelah pemanenan jamur tiram, seluruh limbah baglog diekstrak dan dianalisis aktivitas enzim ligninolitiknya. Pertumbuhan jamur tiram pink di media TKKS memiliki Biological Efficiency Ratio (BER) sebesar 52,08\%, jamur tiram kuning memiliki BER sebesar 41,67\%, dan jamur tiram putih memiliki BER 47,92\%. Aktivitas enzim ligninolitik yang di ektraksi dari limbah baglog pertumbuhan jamur tiram meliputi aktivitas enzim Lignin peroksidase (Li-P) sebesar 0,57 U/mL, Mangan peroksidase (Mn-P) sebesar 34,22 U/mL, dan lakase sebesar 0,04 U/mL.
\end{abstract}

Kata kunci -biomassa pertanian - enzim oksidatif - jamur konsumsi - limbah baglog

\section{Abstract}

Oil palm empty fruit bunches (OPEFB) are potentially exploited in integrative and simultaneous way to produce high-value products, edible mushroom (Pleurotus sp.) and ligninolytic enzymes (Li-P, Mn-P and laccase). Technology System simultaneously can produce Pleurotus sp. and ligninolytic enzyme (oxidative enzyme) can be extracted by fermentation system of solid substrate OPEFB with Pleurotus sp. The purpose of this research is to develop integrative agricultural biomass processing technology of OPEFB,producing OPEFB into high value items through the production of edible mushroom 
and ligninolytic enzymes. The first stage is the growth of Pleurotus ostreatus, Pleurotus flabellatus, and Pleurotus citrinopileatus on OPEFB media. The growth of Pleurotus ostreatus located in Cianjur. After harvesting the Pleurotus sp., the entire baglog waste was extracted and the ligninolytic enzyme activity were analyzed. The growth of Pleurotus flabellatus in medium TKKS having BER 52,08\%, Pleurotus citrinopileatus having BER equal to 41,67\%, and Pleurotus ostreatus having BER 47,92\%. The activity of ligninolytic enzyme extracted from baglog waste of Pleurotus sp. growth includes Lignin peroxidase ( $\mathrm{Li}$ $P$ ) enzyme activity of $0.57 \mathrm{U} / \mathrm{mL}$, Manganese peroxidase $(\mathrm{Mn}-\mathrm{P})$ of $34.22 \mathrm{U} / \mathrm{mL}$, and laccase of $0,04 \mathrm{U} / \mathrm{mL}$.

Keywords - agricultural waste-oxidative enzyme - edible mushroom-baglog waste

\section{Pendahuluan}

Tandang kosong kelapa sawit (TKKS) merupakan limbah dari pengolahan pabrik kelapa sawit yang jumlahnya mencapai 23\% dari tandan buah segar (TBS) yang mampu diolah oleh pabrik kelapa sawit (Laccrose 2004). Seiring bertambahnya pabrik-pabrik pengolahan kelapa sawit maka jumlah TKKS juga akan semakin bertambah. Kandungan TKKS terdiri dari 40,37\% selulosa; 20,06\% hemiselulosa; dan 23,89\% lignin (Yoricya G, et al. 2016). Kandungan TKKS yang masih mengandung lignin dan selulosa bisa dimanfaatkan untuk media pertumbuhan jamur konsumsi dalam hal ini jamur tiram putih (Pleurotus ostreatus) atau jamur tiram (Pleurotus spp.).

Jamur tiram termasuk jamur pelapuk putih dari golongan Basidiomycetes penghasil enzim lignoselulolitik ekstraseluler seperti lignin peroksidase (Li-P), mangan peroksidase (Mn-P) dan lakase (Wesenberg et al. 2003; Siripong et al. 2009); enzim-enzim penghasil $\mathrm{H}_{2} \mathrm{O}_{2}\left(\mathrm{H}_{2} \mathrm{O}_{2}\right.$-generating enzymes), glioksal oksidase dan fenol oksidase (Ohkuma et al. 2001; Khatun et al. 2012). Enzim lakase merupakan enzim pengoksidase polifenol yang mengandung tembaga, yang merupakan katalis yang mereduksi empat elektron ke air dan biasanya disertai oksidasi fenolik substrat ke fenoksil radikal. Enzim Mn-P merupakan enzim yang terdiri dari $\mathrm{Fe}$ yang fenol menjadi fenoksi radikal dengan mengoksidasi $\mathrm{Mn}^{1+}$ menjadi $\mathrm{Mn}^{3+}$ menggunakan $\mathrm{H}_{2} \mathrm{O}_{2}$ sebagai oksidan. Enzim lignin peroksidase juga mengoksidasi senyawa aromatik non fenolik Widiastuti dan Tri Panji (2008) menunjukkan bahwa disamping menghasilkan ketiga enzim tersebut JPP juga menghasilkan veratryl peroksidase yang menggabungkan Li-P dan Mn-P. Enzim ini mengoksidasi senyawa Mn fenolik dan non fenolik.

Jamur tiram yang tergolong jamur pelapuk putih tumbuh cepat dalam limbah lignoselulosa seperti TKKS yang tersedia melimpah dan belum dimanfaatkan secara optimal. Enzim ligninolitik bekerja pada beberapa substrat terutama senyawa fenolik dan hal tersebut merupakan salah satu keunggulan enzim ini (Verma dan Madamwar, 2002). Enzim ligninolitik berguna dalam proses seperti biosorpsi, biobleaching, dan biopulping (Hattaka 1994). Efisiensi proses ligninolisisnya tergantung pada sumber lignoselulosa substrat, struktur komposisi substrat, parameter proses, dan produksi enzim yang dipengaruhi oleh karbon, nitrogen, untuk industri pulp dan kertas. Oleh sebab itu, biodegradasi lignin dapat menjawab tantangan aplikasi bioteknologi pada industri pulp dan kertas (Kirk dan Othmer 1997; Hossain dan Anantharaman 2006). Enzim ligninolitik dapat diestraksi dari limbah TKKS yang dijadikan media tumbuh jamur konsumsi dari golongan Basidiomycetes. Penelitian ini akan mengintegrasikan pertumbuhan jamur tiram pada media TKKS dan ekstraksi enzim ligninolitik dari limbah baglognya. Sehingga akan menghasilkan satu paket teknologi yang memberikan keuntungan cukup besar.

\section{Metoda Penelitian}




\section{Pembuatan baglog media pertumbuhan jamur Pleurotus ostreatus}

TKKS yang digunakan dalam penelitian ini berasal dari PTPN VIII, Kertajaya, Banten. Bahan yang diperlukan untuk membuat baglog sebagai media pertumbuhan jamur tiram adalah TKKS 703,125 gr (70,31\%); serbuk gergaji 234,375 gr $(23,43 \%)$; dedak 44,64 gr (4,46\%); $\mathrm{CaCO}_{3} 13.39$ gr (1,33\%); dan TSP 4,47 gr (0,44\%). Semua bahan dicampur dan diberi air sampai kadar air 55\%. Kemudian dimasukkan dalam plastik-plastik baglog berukuran $1 \mathrm{~kg}$ dan disterilisasi dalam autoklaf suhu $121^{\circ} \mathrm{C}$, tekanan $1 \mathrm{~atm}$ selama $1 \mathrm{jam}$. Jenis jamur yang ditumbuhkan pada baglog TKKS adalah jamur tiram putih, jamur tiram pink (Pleurotus flabellatus), dan jamur tiram kuning (Pleurotus citrinopileatus). Penelitian ini menggunakan rancangan percobaan acak dan perlakuan dilakukan sebanyak 3 ulangan. Jumlah baglog setiap perlakuan adalah 10 baglog. Komposisi baglog yang telah ditentukan yaitu $70,31 \%$ TKKS dan 23,43\% serbuk gergaji diinokulasi dengan bibit jamur tiram sebanyak $1 \% \mathrm{~b} / \mathrm{b}$, ditumbuhkan selama 4 bulan dan setiap bulan sisa baglog tersebut diekstraksi enzim ligninase nya untuk dilihat aktivitas enzim ligninolitiknya.

\section{Inokulasi jamur tiram (Pleurotus ostreatus)}

Kultur Pleurotus ostreatus dan beberapa jenis jamur tiram lain yang ditumbuhkan pada media agar miring selama 2 minggu dipindahkan ke cawan petri (diameter $8 \mathrm{~cm}$ ) dengan media PDA kemudian disebut f0 (kultur murni). Selanjutnya kultur murni dipindahkan ke bibit induk (f1) yang mengandung menir $250 \mathrm{gr}$ dan dedak $1 \mathrm{gr}$ yang diinokulasinya dalam botol jar. Setelah miselium Pleurotus ostreatus memenuhi permukaan f1, kemudian diinokulasikan ke dalam baglog TKKS yang sudah steril.

\section{Pertumbuhan miselium dan pemanenan tubuh buah Pleurotus ostreatus}

Pertumbuhan miselium mulai dihitung pada hari ke-0 sampai hari ke-35 ketika miselium jamur sudah memenuhi permukaan baglog. Setelah itu baglog media tanam dibuka. Tubuh buah pertama muncul 3 hari setelah miselium penuh kemudian dipanen dan ditimbang berat tubuh buahnya. Produktivitas media pertumbuhan jamur tiram ditentukan dengan nilai BER (Biological Efficiency Ratio). Semakin tinggi nilai BER yang dihasilkan maka semakin baik media tersebut. BER dapat dihitung berdasarkan rumus (Bisaria et al., 1987; Jwanny et al., 1995):

$$
B E R=\frac{\text { berat jamur dipanen per musim }}{\text { berat baglog }} \times 100 \%
$$

\section{Perhitungan aktivitas enzim ligninolitik}

Aktivitas enzim ligninase diukur tiap bulan pada baglog jamur selama 3 bulan. Pengambilan sampel dilakukan pada bagian atas, tengah dan bawah baglog media tanam. Pemanenan filtrat enzim dilakukan dengan menggunakan sentrifuse $9000 \mathrm{rpm}, 15$ menit. Supernatan (filtrat) digunakan sebagai sumber enzim. Pengukuran aktivitas enzim lakase berdasarkan metode Buswell et al., 1995; aktivitas mangan peroksidase berdasarkan metode Buswell et al, 1995; dan aktivitas lignin peroksidase berdasarkan metode Tien \& Kirk, 1984. Perhitungan

$$
\begin{array}{ll}
\qquad \text { Akitivitas enzim }=\frac{(A t-A o) x \operatorname{Vtotal}(\mathrm{ml}) \times 10^{6}}{\varepsilon_{\text {maks }} \times d \times \operatorname{Vol~enzim}(\mathrm{ml}) \times t} \\
\text { Ao } \quad=\text { absorbansi awal (menit ke-0) } \\
\text { At } \quad=\text { absorbansi akhir (menit ke-30) } \\
\text { d } \quad=\text { ketebalan kuvet } \\
\varepsilon_{\text {maks }} \quad=\text { absorpsivitas molar }
\end{array}
$$

konsentrasi pereaksi yang digunakan: 
ABTS

: $36000 \mathrm{M}^{-1} \mathrm{~cm}^{-1}$

Guaiacol

: $12100 \mathrm{M}^{-1} \mathrm{~cm}^{-1}$

Veratril alkohol

$$
\text { : } 9300 \mathrm{M}^{-1} \mathrm{~cm}^{-1}
$$

\section{Hasil}

\section{Pertumbuhan miselium jamur tiram}

Isolat jamur tiram yang telah diinokulasi dalam baglog TKKS akan tumbuh dalam waktu kurang lebih 28 hari sampai miselium tumbuh memenuhi permukaan baglog. Pertumbuhan miselium jamur tiram pink, kuning, dan putih dapat dilihat pada Gambar 1.

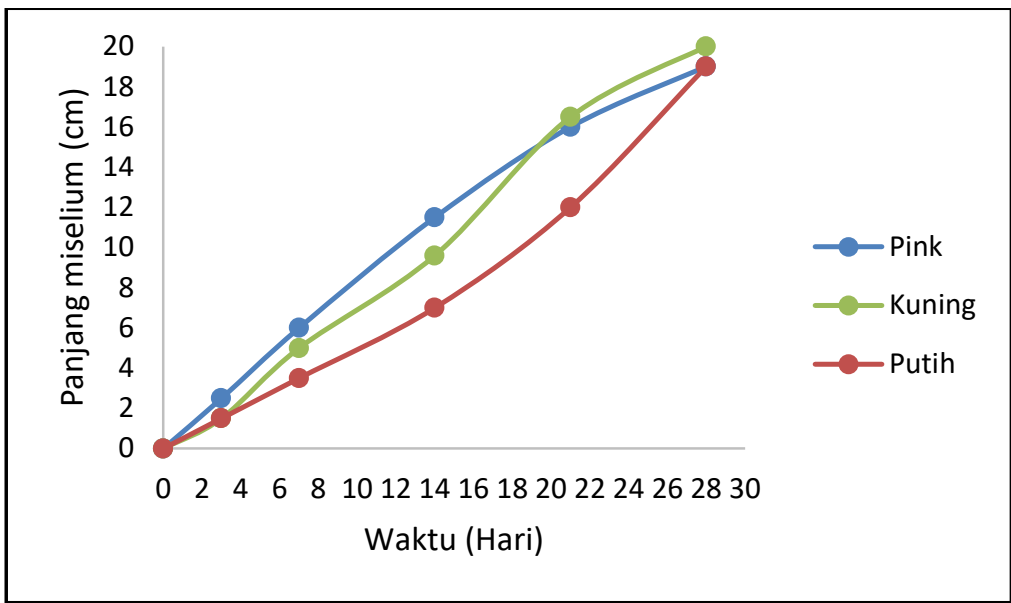

Gambar 1. Grafik pertumbuhan miselium jamur tiram pink, kuning, dan putih

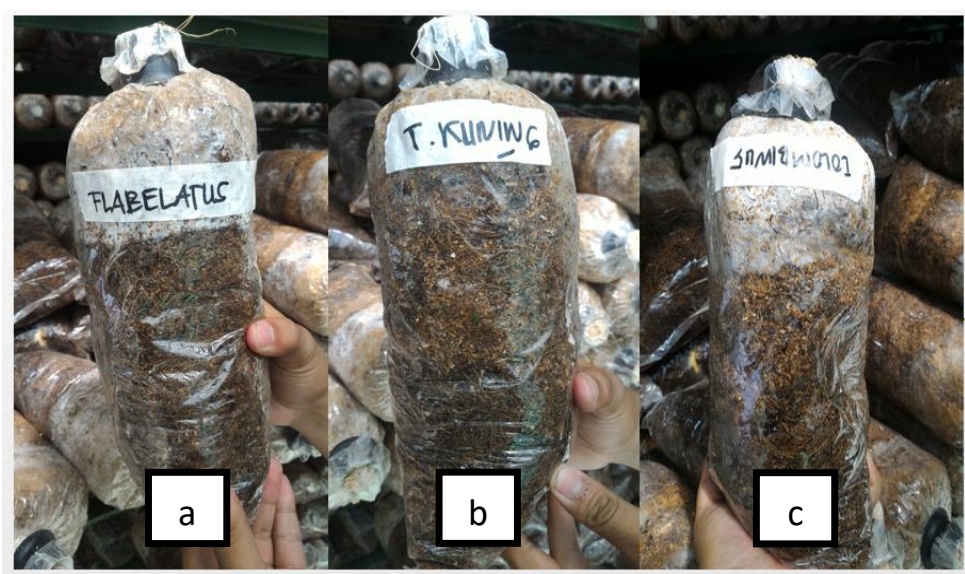

Gambar 2. Pertumbuhan miselium pada baglog TKKS (a) Tiram putih; (b) Tiram pink; (c) Tiram kuning

\section{Produksi tubuh buah jamur tiram}

Produksi tubuh buah jamur tiram pink, kuning, dan putih akan tumbuh 3-7 hari setelah miselium memenuhi permukaan baglog. Produksi tubuh buah jamur tiram dalam satu periode dapat dilihat pada Tabel 1 berikut ini. Sedangkan Gambar 3 menunjukkan gambar tubuh buah jamur tiram yang mulai tumbuh pada baglog.

\section{Aktivitas enzim ligninolitik}

Limbah baglog TKKS masih dimanfaatkan untuk diekstraksi enzim ligninolitiknya (Mn-P, Li-P, dan lakase). Aktivitas enzim diambil setiap bulan (bulan ke-1 sampai bulan ke3) dari limbah baglog pertumbuhan jamur tiram. Lignin peroksidase tertinggi didapat setelah 
bulan ke tiga inkubasi pada bagian atas baglog dengan aktivitas sebesar 0,57 U/mL. Enzim mangan peroksidase juga tinggi pada bulan ke tiga inkubasi namun pada bagian tengah baglog sebesar 39,08 U/mL, sama seperti MnP, lakase dengan ativitas optimum yang diperoleh pada bagian tengah baglog setelah 3 bulan inkubas sebesar 0,04 U/mL.

Tabel 1. Produksi tubuh buah jamur tiram dalam satu periode

\begin{tabular}{|c|c|c|c|c|c|c|c|c|c|}
\hline \multirow[b]{2}{*}{ Panen ke } & \multicolumn{3}{|c|}{$\begin{array}{c}\text { Jamur tiram pink } \\
\text { (Pleurotus flabellatus) }\end{array}$} & \multicolumn{3}{|c|}{$\begin{array}{c}\text { Jamur tiram kuning } \\
\text { (Pleurotus citrinopileatus) }\end{array}$} & \multicolumn{3}{|c|}{$\begin{array}{l}\text { Jamur tiram putih } \\
\text { (Pleurotus ostreatus) }\end{array}$} \\
\hline & $\begin{array}{c}\text { Rata- } \\
\text { rata } \\
\text { (gram) }\end{array}$ & Std dev & $\begin{array}{l}\text { Berat } \\
\text { jamur } \\
\text { setiap } \\
\text { panen } \\
\text { (gram) }\end{array}$ & $\begin{array}{l}\text { Rata-rata } \\
\text { (gram) }\end{array}$ & Std dev & $\begin{array}{l}\text { Berat jamur } \\
\text { setiap } \\
\text { panen } \\
\text { (gram) }\end{array}$ & $\begin{array}{c}\text { Rata- } \\
\text { rata(gram) }\end{array}$ & Std dev & $\begin{array}{l}\text { Berat } \\
\text { jamur } \\
\text { setiap } \\
\text { panen } \\
\text { (gram) }\end{array}$ \\
\hline 1 & 413,33 & 1,53 & 1240 & 431 & 1 & 1293 & 406,67 & 1,53 & 1220 \\
\hline 2 & 439,67 & 0,58 & 1319 & 321,17 & 1,04 & 963,5 & 411 & 1 & 1233 \\
\hline 3 & 556,5 & 0,5 & 1669,5 & 414,33 & 1,15 & 1243 & 504,67 & 0,58 & 1514 \\
\hline 4 & 581 & 1 & 1743 & 421,5 & 0,5 & 1264,5 & 405,83 & 0,76 & 1217,5 \\
\hline 5 & 530 & 1 & 1590 & 408,67 & 1,53 & 1226 & 507,33 & 1,53 & 1522 \\
\hline 6 & 604,17 & 0,76 & 1812,5 & 530,83 & 0,76 & 1592,5 & 513,5 & 0,5 & 1540,5 \\
\hline 7 & 580,5 & 0,5 & 1741,5 & 434,83 & 0,29 & 1304,5 & 540,17 & 1,26 & 1620,5 \\
\hline 8 & 521 & 1 & 15,63 & 540,5 & 0,5 & 1621,5 & 502 & 1,32 & 1506 \\
\hline 9 & 534,17 & 0,76 & $16,02,5$ & 407,83 & 0,76 & 1223,5 & 501,5 & 0,5 & 1504,5 \\
\hline 10 & 495,67 & 0,58 & 1487 & 303,67 & 0,58 & 911 & 520,5 & 0,5 & 1561,5 \\
\hline \multicolumn{3}{|c|}{ Total panen (gram) } & 15768 & & & 12643 & & & 14439,5 \\
\hline & BER (\%) & & 52,56 & & & 42,14 & & & 48,13 \\
\hline
\end{tabular}
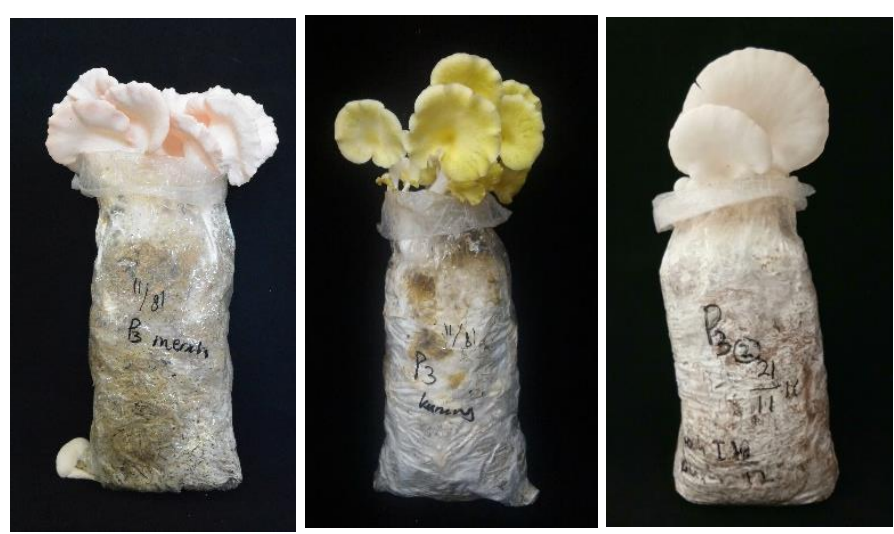

Gambar 3. Tubuh buah Jamur tiram pink, kuning, dan putih yang tumbuh pada baglog TKKS 


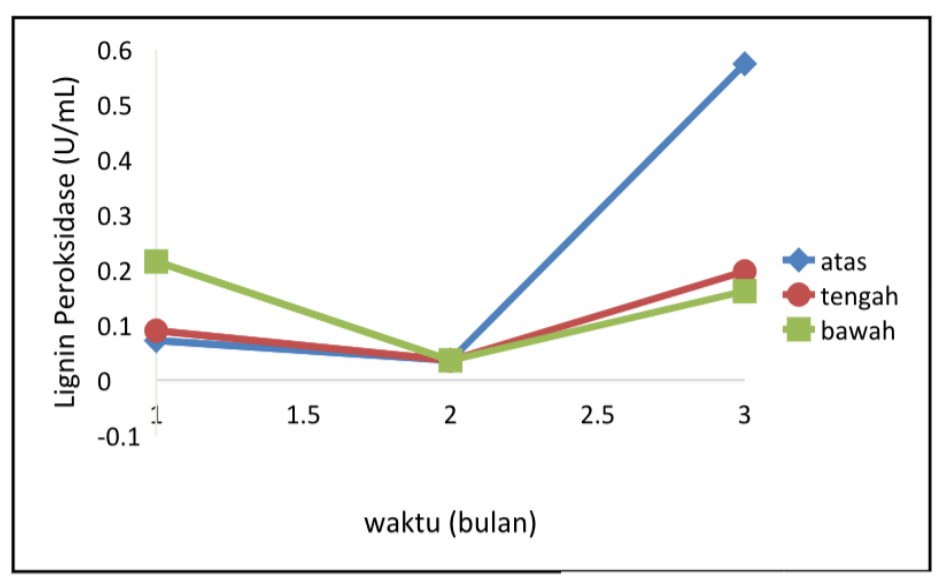

Gambar 4. Aktivitas Lignin Peroksidase dari limbah baglog Pleurotus ostreatus

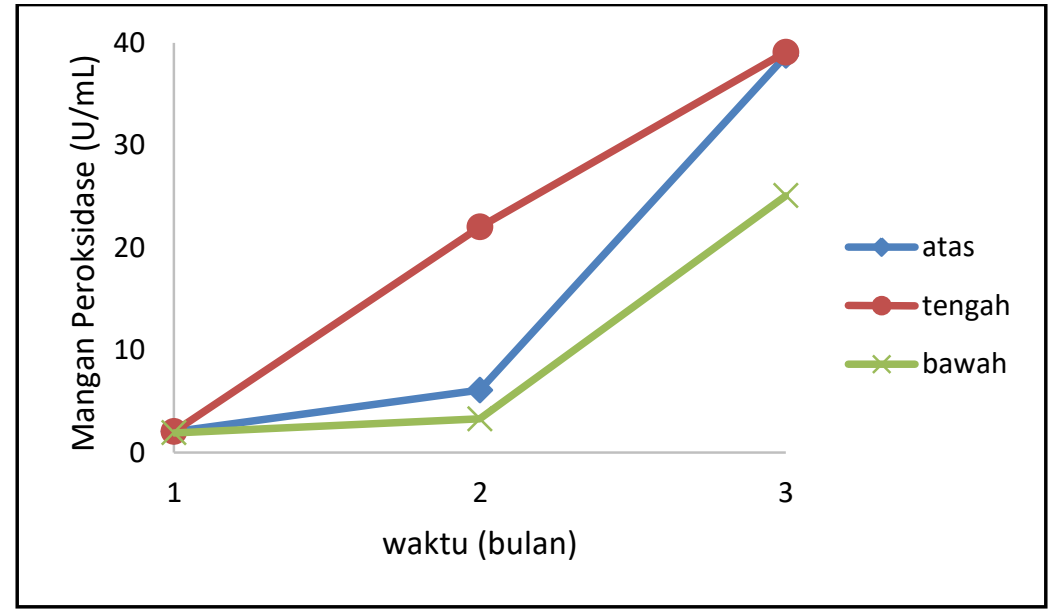

Gambar 5. Aktivitas Mangan Peroksidase dari limbah baglog Pleurotus ostreatus

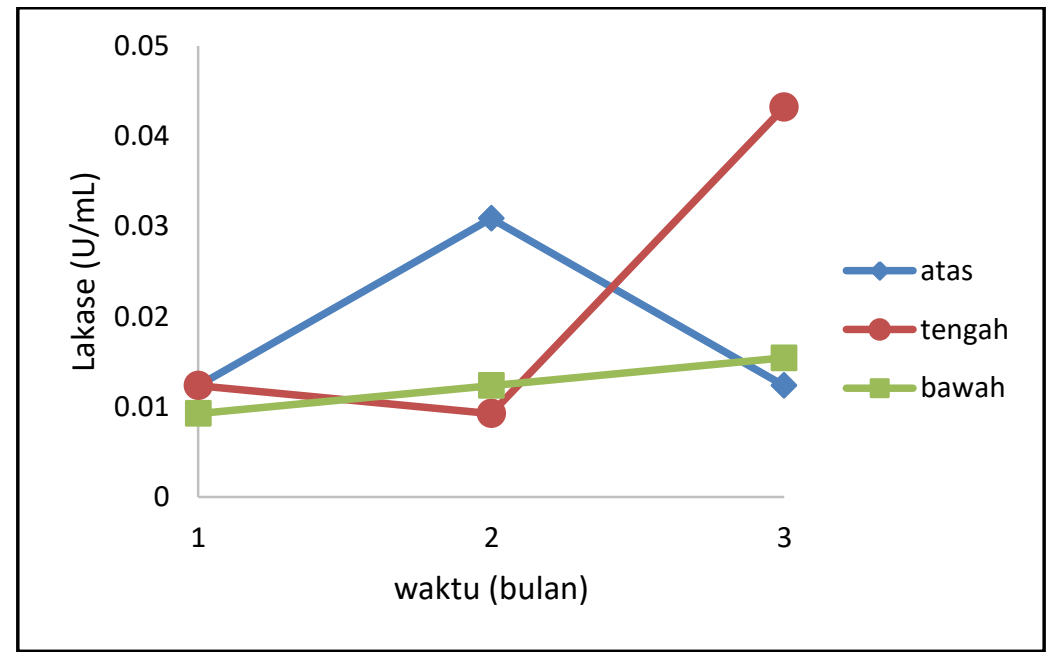

Gambar 6. Aktivitas Lakase dari limbah baglog Pleurotus ostreatus

\section{Pembahasan}

\section{Pertumbuhan miselium jamur tiram}

Miselium jamur tiram pink, kuning, dan putih tumbuh memenuhi permukaan baglog setelah bibit jamur diinokulasikan. Kecepatan pertumbuhan miselium bergantung pada nutrisi yang ada pada media pertumbuhan (baglog). Berdasarkan hasil pengujian di Balai Besar Pulp dan Kertas, TKKS masih mengandung lignin 26,49\%; hemiselulosa 17,01\%; dan selulosa 
40,61\%. Miselium jamur menyerap nutrisi dalam bentuk ion dan molekul sederhana (Dashi dan Singh, 1991). Nutrisi yang diperlukan untuk pertumbuhan jamur terdapat di TKKS. Jamur tiram termasuk dalam golongan jamur basidiomycetes yang mampu mendegradasi lignin (Wesenberg et al., 2003; Siripong et al., 2009). Pertumbuhan miselium jamur tiram pink, kuning, dan putih tidak terlalu berbeda rata-rata pertumbuhan miselium telah memenuhi permukaan baglog pada hari ke-28 (Gambar 1). Hal ini sesuai dengan penelitian Lin et al., 2015 yang menumbuhkan Pleurotus ostreatus pada baglog yang mengandung media TKKS. Miselium mulai tumbuh pada hari ke-2 dan memenuhi permukaan baglog pada hari ke-28. Pertumbuhan miselium jamur tiram pink terus bertambah dari hari ke-2 dan mengalami peningkatan yang banyak ketika hari ke- 8 sebesar $4 \mathrm{~cm}$, hal ini bisa dilihat pada Gambar 1 . Sedangkan pertumbuhan miselium jamur tiram kuning ada penurunan pada hari ke-14 namun terus bertambah pada hari hari berikutnya.

\section{Produksi tubuh buah jamur tiram}

Pleurotus ostreatus memiliki sel-sel yang dapat berdiri sendiri atau saling berhubungan sehingga membentuk benang hifa. Kumpulan benang hifa membentuk miselium kemudian dari miselium terbentuk gumpalan kecil seperti simpul menyerupai urat akar. Simpul miselia bermuara membentuk bulatan kecil yang disebut pinhead disebut juga sebagai periode primordia yang selanjutnya menjadi stadium dewasa (fruiting body) dan akhirnya membentuk tubuh buah yang sempurna yang terdiri dari batang (stipe) tanpa cincin dan tudung (pileus) (Adinata dan Hendritomo, 2002). Pileus bebentuk seperti cangkang tiram berukuran $5-15 \mathrm{~cm}$ dan permukaan bagian bawah berlapis-lapis seperti insang, berwarna putih dan lunak. Sedangkan panjang pendeknya tangkai bergantung pada kondisi lingkungan.

Pembentukan tubuh buah pada jamur tiram putih ( $P$. ostreatus) dan kuning $(P$. citrinopileatus) masih meningkat setelah 3 bulan inkubasi, Jamur Tiram Pink ( $P$. flabellatus) terus menurun. Jamur tiram putih memiliki bobot yang paling tinggi, hal tersebut dikarenakan perkembangan tubuh buah dari jamur dipengaruhi oleh akivitas enzim yang dihasilkan oleh jamur tersebut. Semakin tinggi tubuh buah yang dihasilkan maka substrat dari medium akan semakin berkurang (Kues dan Liu, 2000)

\section{Aktivitas enzim ligninolitik}

Lignin peroksidase

Aktivitas lignin peroksidase paling tinggi berasal dari bagian baglog paling atas setelah tiga bulan inkubasi (Gambar 5). Pada bulan ke tiga sumber nutrisi dalam baglog seperti karbon dan nitrogen sudah mulai habis untuk pertumbuhan jamur. Bagian atas baglog yang diselimuti miselium lebih banyak menghasilkan aktivitas lignin peroksidase yang paling tinggi. Hal ini dikarenakan lignin peroksidase diproduksi dalam keadaan miskin hara (karbon dan nitrogen) (Placido and Capareda, 2015).

\section{Mangan peroksidase}

Aktivitas mangan peroksidase tertinggi ada pada bulan ke tiga sebesar $39 \mathrm{U} \mathrm{ml}^{-1}$. Bagian atas maupun tengah memiliki aktivitas yang hampir sama, bagian bawah baglog menghasilkan akivitas MnP paling rendah (Gambar 6). Aktivitas MnP meningkat pada akhir pemanenan, pola ini sama dengan hasil riset dari (Lechner \& Papinutti, 2006) dimana MnP tertinggi didapat pada akhir kultivasi dengan nilai $0,75 \mathrm{U} \mathrm{g}^{-1}$.

\section{Lakase}

Pola aktivitas lakase berbeda di setiap bagian baglog. Pada bulan pertama diseluruh bagian baglog aktivitas lakase sekitar $0,01 \mathrm{U} \mathrm{ml}^{-1}$. Aktivitas lakase pada baglog bagian atas 
tinggi pada saat pertengahan inkubasi, pola ini sama dengan dari (Lechner and Papinutti, 2006). Hal ini kemungkinan enzim lakase dibutuhkan untuk memecah substrat yang dibutuhkan untuk pertumbuhan enzim.

Berdasarkan beberapa hasil di atas dapat diketahui bahwa limbah TKKS dapat dimanfaatkan sebagai media pertumbuhan jamur tiram putih (Pleurotus ostreatus) dengan BER sebesar 52,56\% untuk jamur tiram pink, 41,14\% untuk jamur tiram kuning, dan 48,13\% untuk jamur tiram putih. Aktivitas enzim ligninolitik yang diektraksi dari limbah baglog meliputi enzim Lignin peroksidase (Li-P) dengan aktivitas sebesar 0,57 U/mL, Mangan peroksidase (Mn-P) sebesar 34,22 U/mL, dan lakase sebesar 0,04 U/mL.

\section{Ucapan Terima Kasih}

Penelitian ini terlaksana atas bantuan dana dari program Badan Pengelola Dana Perkebunan Kelapa Sawit (BPDPKS) dengan perjanjian Nomor: PRJ - 40/DPKS/2016 Tanggal: 30 Agustus 2016. Peneliti mengucapkan terima kasih atas kepercayaan BPDPKS mendanai penelitian ini.

\section{Pustaka}

Adinata G.S. dan Hendritomo H.I. 2002- Biologi Jamur Pangan. Pusat Pengkajian dan Penerapan Teknologi Bioindustri. Jakarta.

Bisaria, R., Madan, M., Bisaria, V.S. 1987- Biologycal efficiency and nutritive value of Pleurotus sajor-caju cultivated on different agrowastes. Biol Waste 19: 239-255.

Buswell, J.A., Yijin C, Shu-ting C. 1995- Effect of nutrient nitrogen and manganase on manganase peroxidase and laccase production by Lentinula (Lentinus) edodes. FEMS Microbiol Lett 128 (1): 81-87.

Dashi, A., and R.D. Singh. 1991- Toxic effect of cultuire filtrates of different taulakinant fungi Pleurotus sayor-caju. Indian Phytopath.44(2):231-232.

De Jong E, Field JA, and De Bont JAM(1992) - FEBS Lett 299, 107-110

Hatakka A 1994- Lignin modifying enzyme from selected white-rot fungi : production and role in lignin degradation. FEMS Microbiol. Rev $13: 125-135$.

Hossain SM and N Anantharaman. 2006- Activity Enhancement of Ligninolytic Enzymes of Trametes versicolor with Bagasse Powder," African Journal of Biotechnology 5(1):189-194

Jwanny, EW., Rashad, M.M., Abdi H.M. 1995- Solid-state fermentation of agricultural waste into food through Pleurotus cultivation. Appl Biochem. Biotechnol 50: 71-78.

Khatun S, MD Ashraduzaman, MR Karim, F Pervin, N Absar \& A Rosma. 2012Purification and characterization of peroxidase from Moringa oleifera leaves. Bio Resources 7 (3): 3237-3251.

Kirk, R.E. and D.F. Othmer. 1997- Cellulose encyclopedia of chemical technology, John Wiley,New York, 4: 593-683

Kues U \& Y.Liu. 2000 - Fruiting body produstion in basidiomycetes. Appl Microbial Biotechnol 54: 141-152.

Lechner, B.E. and V.L. Papinutti.2006- Production of lignocellulosic enzymes during growth and fruiting of the edible fungus Lentinus tigrinus on wheat straw. Process Biochemistry 41:594-598

Lin, M., Setiarti Sukotjo, Sidik Marsudi. 2015- Potential of oil palm empty fruit bunch (EFB) as media for Oyster mushroom, Pleurotus ostreatus cultivation. Procedia Chemistry 16: 427-431.

Ohkuma, M, Y Maeda, T Johjima \& T Kudo. 2001-Lignin degradation and roles of white rot fungi: Study on an efficient symbiotic system in fungus-growing termites and its 
application to bioremediation. RIKEN Focused on Ecomolecular Science Review 42: 39-42.

PlácidoJ. and S. Capareda.2015-Ligninolytic enzymes: a biotechnologicalalternative for bioethanolproduction. Bioresources and Bioprocessing, 2:23

Siripong P, B Oraphin, T Sanro \& P Duanporn. 2009- Screening of fungi from natural sources in Thailand for degradation of polychlorinated hydrocarbons. AmericanEurasian Journal of Agricultural \& Environmental Science 5 (4): 466-472.

Tien, M. \& T. K. Kirk. 1984- Lignin degrading enzyme from Phanerochaete chrysosporium: Purification, characterization, and catalytic properties of a unique $\mathrm{H} 2 \mathrm{O} 2$-requiring oxygenase. In Proc. Natl. Acad. Sci.USA, 81, 2280-2284.

Verma P \& Datta M. 2002- Production of ligninolytic enzymes for dye decolorization by cultivation of white-rote fungi Pleurotus ostreatus and Phanerochaete chrysosporium under solid-state fermentation. Humana Press Inc 0273-2289.

Wesenberg D, I Kyriakides, SN Agathos. 2003-White-rot fungi and their enzymes for the treatment of industrial dye effluents. Biotechnology Advances $22: 161-187$.

Widiastuti H dan Tri Panji. 2008-Pola aktivitas enzim ligninolitik Pleurotus ostreatus pada limbah sludge pabrik kertas. Menara Perkebunan 76(1), 47-60.

Yoricya G, SA Putri, Dalimunthe, R Manurung, N Bangun. 2006- Hidrolisis Hasil Delignifikasi Tandan Kosong Kelapa Sawit dalam Sistem Cairan Ionik Choline Chloride. Jurnal Teknik Kimia 5 (1): 27-32. 